\title{
The role of Molecular Markers in Improvement of Fruit Crops
}

\author{
Zahoor Ahmad BHAT ${ }^{1)}$, Wasakha Singh DHILLON ${ }^{1)}$, Rizwan RASHID ${ }^{2)}$, Javid \\ Ahmad BHAT ${ }^{3}$, Waseem Ali DAR ${ }^{4}$, Mohammad Yousf GANAIE') \\ 1) Punjab Agricultural University, Department of Horticulture, Ludhaina-141004, India; \\ zahoornano@gmail.com,wasakhasingh@yahoo.com,abdulzz10@gmail.com \\ 2) Punjab Agricultural University, Department of Vegetable Crops, Ludhaina-141004, India; rizwan60@gmail.com \\ 3)Punjab Agricultural University, Department of Plant Pathology, Ludhaina-141004, India; javidrashid635@gmail.com \\ 4) Punjab Agricultural University, Department of Plant Pathology, Skaust Shalimar-191121, India; luckywasim_2003@yahoo.com
}

\begin{abstract}
Markers have been used over the years for the classification of plants. Markers are any trait of an organism that can be identified with confidence and relative easy, and can be followed in a mapping population on another hand markers be defined as heritable entities associated with the economically important trait under the control of polygenes. Morphological markers can be detected with naked eye (naked eye polymorphism) or as difference in physical or chemical properties of the macromolecules. In other words, there are two types of genetic markers viz. morphological markers or naked eye polymorphism and non-morphological markers or molecular markers. Morphological markers include traits such as plant height, disease response, photoperiod, sensitivity, shape or colour of flowers, fruits or seeds etc. Molecular markers include biochemical constituents. Morphological markers have many limitations for being used as markers particularly in fruit crops because of long generation time and large size of fruit trees besides being influenced by environment. Consequently, molecular markers could be appropriate choice to study and preserve the diversity in any germplasm. Molecular markers have diverse applications in fruit crop improvement, particularly in the areas of genetic diversity and varietal identification studies, gene tagging, disease diagnostics, pedigree analysis, hybrid detection, sex differentiation and marker assisted selection.
\end{abstract}

Keywords: markers, DNA, morphological, polygenes, diversity

\section{Introduction}

The markers have been used over the years for the classification of plants. Markers are any trait of an organism that can be identified with confidence and relative ease, and can be followed in a mapping population with other words, they can be defined as heritable entities associated with the economically important trait under the control of polygenes (Beckman and Soller, 1986). Morphological markers can be detected with naked eye (naked eye polymorphism) or as difference in physical or chemical properties of the macromolecules. Therfore, there are two types of genetic markers, respectively: morphological markers or naked eye polymorphism and non-morphological markers or molecular markers.

\section{Morphological markers}

Morphological markers are those traits that are scored visually, or morphological markers are those genetic markers whose inheritance can be followed with the naked eye. The traits included in this group are plant height, disease response, photoperiod, sensitivity, shape or color of flowers, fruits or seeds etc. Although they are generally scored quickly, simply and without laboratory equipments, such markers are not put too much use. because of the following reasons: genotypes can be ascertained generally at whole plant or plant organ level and frequently the mature plant is used. Such markers frequently cause major alternations in the phenotype which is undesirable in breeding programs. Dominant, recessive interactions frequently prevent distinguishing all genotypes associated with morphological traits. Morphological markers masks the effect of linked minor gene, making it nearly impossible to identify desirable linkages for select and are limited in number, influenced by environment and also specific stage of the analysis.

\section{Non-morphological markers or molecular markers}

Until recently virtually all progress in both breeding and modern genetics have relied on the phenotypic or morphological assay. But with the advent of molecular markers a new generation of markers was introduced over the last two decades that have become an important tool in the genetic improvement of crop species and has changed the entire scenario of biological sciences. Molecular markers are any kind of molecule indicating the existence of a chemical or a physical process. Molecular markers include biochemical constituents (e.g. secondary metabolites in plants) and macromolecules (e.g. proteins and deoxyribonucleic acid) (Joshi et al., 1999). These macromolecules 
Tab. 1. Comparison between morphological, isozyme and DNA markers

\begin{tabular}{|c|c|c|c|}
\hline Feature & Morphological markers & $\begin{array}{c}\text { Biochemical molecular } \\
\text { markers }\end{array}$ & DNA based markers \\
\hline $\begin{array}{l}\text { Feature of the } \\
\text { organism scored }\end{array}$ & Phenotype & Protein & DNA base sequence \\
\hline $\begin{array}{l}\text { Biological meaning } \\
\text { of the markers }\end{array}$ & Consequences of gene action & Genes that are expressed & $\begin{array}{l}\text { DNA sequences, may or may } \\
\text { not represent genes }\end{array}$ \\
\hline $\begin{array}{l}\text { Plant material required } \\
\quad \text { for detection }\end{array}$ & Intact plant or plant organ & Little amount of tissue & $\begin{array}{l}\text { Little to medium amount of tissue } \\
\text { and no matter what tissue is used }\end{array}$ \\
\hline $\begin{array}{l}\text { Efforts required } \\
\text { for detection }\end{array}$ & Simple & Moderate & Moderate to difficult \\
\hline Ease of use & Very easy & Moderately difficult & Moderately difficult to difficult \\
\hline Reproducibility & High & High & Moderate to high \\
\hline Dominance/ Codominance & Generally dominant & Codominant & $\begin{array}{l}\text { Dominant (RAPD, AFLP) } \\
\text { Codominant (RFLP, SSR) }\end{array}$ \\
\hline
\end{tabular}

show easily detectable differences among different strains of a species or among different species. Strauss et al. (1992) distinguished the molecular markers into two classes. Biochemical molecular markers derived from the chemical products of gene expression i.e. protein based markers and molecular genetic markers derived from direct analysis of polymorphism in DNA sequences i.e. DNA based markers presented in (Tab. 1)

\section{Biochemical molecular markers}

The first biochemical molecular markers used were the protein based markers. Proteins are attractive for direct genetic study because they are the primary products of structural genes. Changes in coding base sequence will under many circumstances, resulting in corresponding changes in the primary structure of proteins. Even single amino acid substitutions, deletions or additions can have marked effects on the migration of proteins under an electric field during electrophoresis. One of the earliest protein based markers to be used was Isozyme. Market and Moller (1959) coined the term to describe the multiple molecular forms of the same enzyme with the same substrate specificity. Isozymes are different forms of an enzyme exhibiting the same catalytic activity but differing in charge and electrophoretic mobility. In Isozyme analysis, crude plant extracts are subjected to electrophoresis using starch or polyacrylamide gels. Following electrophoresis, the enzymes of interest are detected by treating the gels with specific activity stains. Variation in bending patterns obtained between individual samples can be used to sort out genetically the varieties tested.

\section{DNA based markers}

DNA contains individual genetic blue print. The sequence of nucleotides in DNA of an individual is unique and thus determines its identity. The ultimate difference between individuals lies in the nucleotide sequence of their DNA. The detection of such differences employing different molecular biological techniques led to the development of DNA markers. On plants DNA markers were first developed in $1985-86$ by two groups of researchers working independently at native plants incorporated, USA and Cornell University Ithaca USA. DNA markers should not be considered as normal genes, as they usually do not have any biological effect and instead can be thought of as constant landmark in the genome. DNA markers are the identifiable DNA sequences found at specific locations on the chromosomes and transmitted by the standard laws of inheritance from one generation to the next one. They rely on DNA assay in contrast to morphological markers based on visible traits and biochemical molecular markers based on protein products by gene. So DNA is an ideal molecule for studying polymorphism. DNA markers can be used to diagnose the presence of the gene without having to wait for gene effect to be seen (Peterson et al., 1991)

\section{Properties desirable for ideal DNA Markers}

Highly polymorphic in nature; codominant expression; selectively neutral behaviour; easy access and assay; easy exchange of data between laboratories; follow Mendelian inheritance; genetically linked to trait in question.; not affected by pleiotropism and epistatic interactions

The different molecular marker technologies that are available today can be classified into two broad categories: based on molecular hybridisation and based on Polymerase Chain Reaction (DNA amplification).

\section{Restriction Fragment Length Polymorphism (RFLP)}

This is the first marker system that was conceived and developed by Botstein et al. (1993) and is based on southern blotting hybridization technique. If genomic DNA's are digested with restriction enzyme, electrophoresis, blotted on nitrocellulose membrane and detected with labelled probe, then polymorphism in the hybridization pattern is revealed due to the change in restriction cleavage site. Such variation is termed as Restriction Fragment Length Polymorphism. To use this technique a set of chromosomal DNA fragments are prepared as probes, such a set of probe is called library. DNA isolated from the species of interest is digested with restriction enzyme and 
24

relatively small fragments are legated in bacterial plasmid, afterwards the plasmid is transferred into bacterial cell. By growing the transferred bacteria one obtains a large supply of a single plant DNA restriction fragments which is suitable for use as hybridization probe. When DNA from a strain is digested by restriction enzyme, many different size fragments are produced. The DNA fragments so formed are identified by southern blotting (Southern, 1975), a procedure by which DNA fragments can be separated by gel electrophoresis. Small fragments migrate more rapidly through the pores of gel then larger ones. The separated fragments are transferred to a nitrocellulose membrane support. The nitrocellulose membrane is removed from the blotting stack and baked in vaco at $80^{\circ} \mathrm{C}$ so as to permanently immobilize the DNA on the membrane. The labeled DNA probe is then hybridized to separate DNA and finally the labeled DNA probe hybridized to complementary DNA bands are visualized by autoradiography. The number of fragments obtained and their size depends upon the number of restricted sites and their position on DNA which in turn is characteristic of the genome sequence which is being analyzed (Tab. 2).

Tab. 2. Successful examples of RFLP techniques in fruit crops

\begin{tabular}{cccc}
\hline $\begin{array}{c}\text { S. } \\
\text { No. }\end{array}$ & $\begin{array}{c}\text { Plant } \\
\text { Species }\end{array}$ & Work Done & References \\
\hline 1. & Peach & $\begin{array}{c}\text { Genetic linkage } \\
\text { mapping }\end{array}$ & Rajapakse et al. (1995) \\
2. & Sour Cherry & $\begin{array}{c}\text { QTL analysis of } \\
\text { flower and fruit traits }\end{array}$ & Wang et al. (2000) \\
\hline
\end{tabular}

\section{Polymerase Chain Reaction (PCR) based on molecular} markers

The discovery of polymerase chain reaction method of DNA amplification by Mullis et al. (1986) is an important milestone in molecular biological research. PCR is an in-vitro method for enzymatic amplification of a specific DNA segment from the genomic DNA.

\section{Random Amplified Polymorphic DNA (RAPD)}

PCR based markers developed by William et al. (1990). Primers (usually a decamer) with arbitrary sequences (random primers) are used for amplification, DNA segments to be amplified will be selected at randomly and this provides a truly random samples of DNA markers and so is described as RAPD. In this technique primers are designed. A single primer is a short oligonucleotide of random chosen DNA sequence with at least 50\% GC content. This process starts by extracting the genomic double stranded DNA which is made single stranded by heating at $920^{\circ} \mathrm{C}$ for a minute. At this stage primer hybridizes with the homologous genomic DNA and then a new strand is synthesized using enzyme taq polymerase. Separation of reaction products is achieved on standard agarose gel which is then visualized with ethedium bromide staining. It is observed that the nature of amplified fragments is dependent on the primer sequence as well as of the DNA sequence of the genome being assayed. Primers differing by even a single nucleotide results in indifferent amplified bands. A primer usually amplifies several bands each originating from a different genome location. In a strain which has in its genomic DNA, sequences complementary to the primer oligonucleotide PCR products will be detected in the gel while in those strains that do not have complementary sequences, no product will be detected in the gel (Tab. 3)

Tab. 3. Successful examples of RAPD techniques in fruit crops

\begin{tabular}{cccc}
\hline $\begin{array}{c}\text { S. } \\
\text { No. }\end{array}$ & $\begin{array}{c}\text { Plant } \\
\text { Species }\end{array}$ & Work Done & References \\
\hline 1. & Peach & $\begin{array}{c}\text { Identification of } \\
\text { peach cultivars }\end{array}$ & Lu Zx et al. (1996) \\
2. & Peach & $\begin{array}{c}\text { Comparison of } \\
\text { genetic diversity }\end{array}$ & $\begin{array}{c}\text { Warburton } \text { et al. } \\
(1996)\end{array}$ \\
3. & Almond & $\begin{array}{c}\text { Genetic relatedness among } \\
\text { cultivars and breeding lines }\end{array}$ & $\begin{array}{c}\text { Bartolozzi } \text { et al. } \\
(1998)\end{array}$ \\
\hline
\end{tabular}

\section{Simple Sequence Repeats (microsatellites)}

Simple sequence repeats (SSRs), also known as microsatellites, are present in the genomes of all eukaryotes. These are ideal DNA markers for genetic mapping and population studies because of their abundance. These are tandemly arranged repeats of mono-, di-, tri-, tetra- and penta-nucleotides with different lengths of repeat motifs (e.g. A, T, AT, GA, AGG, AAC, etc.). These repeats are widely distributed throughout plant and animal genomes that display high levels of genetic variation based on differences in the number of tandemly repeating units at a locus. These SSR length polymorphisms at individual loci are detected by PCR, using locus-specific flanking region primers where the sequence is known. Thus, STMs require precise DNA sequence information for each marker locus from which a pair of identifying flanking markers are designed. This is impractical for many plant and animal species that are not well-characterized genetic systems. Some of these SSR-based methods have been collectively termed mocrosatellite-primed PCR (MP-PCR).

\section{Steps of SSRs analysis}

Isolate the DNA of representative cultivar/line; restrict with 4 base pair cutter; size fractionation (0.5-0.7 $\mathrm{kb}$ ); ligate to a suitable vector and transform into E.coli; following hybridization identify the desired transformation; go for end sequencing of the selected clones; design the primers for amplification.

Advantages of SSRs are: codominant markers; highly polymorphic; highly reproducible.

Disadvantage is costly primer developing.

\section{Inter Simple Sequence Repeat (ISSR)}

Since 1994, a new molecular marker technique called inter simple sequence repeat (ISSR) has been available (Zietkiewicz et al., 1994). ISSRs are semiarbitrary mark- 
ers amplified by PCR in the presence of one primer complementary to a target microsatellite. Amplification in the presence of nonanchored primers also has been called microsatellite-primed PCR, or MP-PCR (Meyer et al., 1993). Such amplification does not require genome sequence information and leads to multilocus and highly polymorphous patterns (Zietkiewicz et al., 1994; Tsumara et al., 1996; Nagaoka et al., 1997). Each band corresponds to a DNA sequence delimited by two inverted microsatellites. Like RAPDs, ISSRs markers are quick and easy to handle, but they seem to have the reproducibility of SSR markers because of the longer length of their primers.

\section{Sequence Characterized Amplified Regions (SCAR)}

Martin et al. (1991) and Michelmore et al. (1991) succeeded in producing SCAR. This is also an PCR based marker technique in which the RAPD marker associated with desired locus is eluted from gel. The termini's are then sequenced and long primer (22-24 nucleotide base long) are designed for the specific locus. Specific locus amplification is followed by gel electrophoresis for size separation for locus specific band detection.

\section{Amplified Restriction Fragment Length Polymorphism} or Selective Restriction Fragment Amplification (AFLP)

Amplified restriction fragment length polymorphism is a powerful DNA fingerprinting technology developed by Vos et al. (1995) based on PCR amplification of a set of restriction fragments, selected from a pool of fragments that are generated due to digestion with a pair of specific restriction enzymes, one of them being a frequent cutter and the other a rare cutter.

This technique involves three steps; firs, restriction of DNA and ligation of oligonucleotide adapters, second, selective amplification of sites of restriction fragments and last, gel analysis of the amplified fragments.

The total genomic DNA is first digested with two enzymes: a rare cutter (e.g. EcoRI or Pst-I) which reduces the number of fragments to be amplified and a frequent cutter (eg. MseI or Taq I) which generates small DNA fragments that will amplify well and are in the optimal size range for separation of gel. Thus there is a selective amplification of higher number of restriction fragments generated. The fragments are ligated to the appropriate adapters and used for PCR amplification with two AFLP primers, each having a single selection nucleotide: this is called pre-amplification step. The PCR products from this preamplification step are diluted and used as template for the second PCR amplification. In this step each of two primers has up to three selection of nucleotides. The amplified fragments are separated on sequence in gel and visualized by silver staining: alternatively the primers are labeled either by radioisotopes or fluorescent dye so that the AFLP profile can be obtained by auto radiograph.

In India ICAR has been supporting projects on DNA fingerprinting in a number of institutes. Some of which are showen in Tab. 4.

\section{Applications of molecular markers}

Assessment of genetic diversity, identification of QTLs, gene cloning, varietal diagnosis, diseases diagnosis, marker assisted selection (MAS) and linkage map.

\section{Assessment of genetic diversity}

A number of reports are available on the use for DNA markers to assess genetic diversity among species of several horticultural crops, as well as validation of genetic relatedness among them. This has significant application, especially for difficult to breed woody perennials. Using RAPD markers the wide variability was observed in the mandarin germplasm present in N. E. Himalayas. In China using SSR markers, genetic diversity in mandarin landraces and wild races of mandarins, sweet orange, mandarins, grapefruit, lemon and citranges was resolved. DNA markers have also been utilized to find out the phylogenetic relationships in 30 accessions of true Citrus fruits ('Fortunella', 'Eremocitrus', 'Microcitrus', 'Clymenia' and 'Citrus'). The different types of markers that have been used for assessment of genetic diversity are presented as folow in Tab. 5 .

Tab. 4. Supporting institutes on DNA projects

\begin{tabular}{|c|c|c|}
\hline Institute & Crop & Work \\
\hline IIHR & $\begin{array}{l}\text { Mango, Citrus, } \\
\text { Pomegranate }\end{array}$ & $\begin{array}{l}\text { i) Identification of Mango varieties and genetic relatedness through RAPDS } \\
\text { ii) Identification of markers linked to bacterial canker resistance in Lemon } \\
\text { iii) Development of markers to test clonal fidelity of pomegranate plants raised through tissue culture. }\end{array}$ \\
\hline $\begin{array}{l}\text { CPCRI- } \\
\text { Kasargod }\end{array}$ & Coconut & $\begin{array}{l}\text { i) Standardization of protocol for DNA extraction } \\
\text { ii) DNA fingerprinting of all major coconut accessions, hybrids } \\
\text { and high yielding palms using RFLP,RAPD markers } \\
\text { iii) Development of molecular markers linked with important traits especially } \\
\text { root wilt disease resistance/tolerance and drought tolerance. }\end{array}$ \\
\hline NRC-Trichy & Banana & $\begin{array}{l}\text { i) Typing of Musa genotypes using isozymes, RAPD and RFLP } \\
\text { ii) Marker aided selection for important traits } \\
\text { iii) DNA finger printing of new Musa clones }\end{array}$ \\
\hline CISH-Lucknow & Mango & $\begin{array}{l}\text { DNA fingerprinting for identification and analysis of existing } \\
\text { genotypes, promising new hybrids and clones of mango }\end{array}$ \\
\hline
\end{tabular}


Tab. 5. DNA Markers for Genetic Diversity Assessment in Fruit Crops

\begin{tabular}{ccc}
\hline Fruit & Marker Type & References \\
\hline Apple & AFLP and RAPDs & Coart et al. (2003); Botez et al. (2009); Sestras et al. (2009) \\
Avocado & Mini satellite DNA & Ashworth et al. (2003) \\
Banana & RAPDs & Brown et al. (2009) \\
Citrus & RFLP & Durham et al. (1992) \\
Grapes & RFLP and SSRs & Bourquin et al. (1993) \\
Mango & He et al. (2007) \\
Pistachio & cpISSR and RAPDs & Marcela et al. (2009) \\
Cashew & Mini satellite marker & Riaz Ahmad et al. (2003) \\
Pear & RAPD and ISSR & Thimmappaiah et al. (2009) \\
\hline & SSRs and AFLP & Sisko et al. (2009) \\
\hline
\end{tabular}

\section{Identification of QTLs}

Many important heritable characters are a consequence of the joint action of several genes. Such characters are often referred to as polygenic or quantitative. Several characters of plant species, among which are traits of agronomic importance, are inherited quantitatively. Yield, maturity date and drought tolerance are examples of such characters. The genetic loci for such characters have been referred to as quantitative trait loci (QTLs). The essential feature which makes feasible the finding and characterization of a QTL is its linkage with a known marker locus segregating with Mendelian ratios. DNA markers provide this opportunity by making it feasible to identify, map and measure the effects of genes underlying quantitative trait .In grape QTLs were use for features such as like Critical Photoperiod, growth cessation, or dormancy, bud break (BB) and winter hardiness (Tab. 6).

Approximate position of 28 major genes were mapped in different populations of peach (orange background), almond (yellow background) and Myrobalan plum (green background) on the framework of the Prunus reference map. Gene abbreviations correspond to: $Y$, peach flesh colour; sharka, plum pox virus resistance; $M i$, nematode

Tab. 6. Markers associated to main polygenic traits in fruit crops

\begin{tabular}{cccc}
\hline Fruit & Trait & Marker Type & References \\
\hline Apple & Fire blight resistance & SCAR, SSR & $\begin{array}{c}\text { Sylwia } \text { et al. } \\
(2009)\end{array}$ \\
Citrus & $\begin{array}{c}\text { Citrus leprosis } \\
\text { virus resistance }\end{array}$ & $\begin{array}{c}\text { AFLP and } \\
\text { RAPD }\end{array}$ & $\begin{array}{c}\text { Bastianel } \text { et al. } \\
(2009)\end{array}$ \\
Pear & Incompatibility & AFLP and SSR & $\begin{array}{c}\text { Sun } \text { et al. } \\
(2009)\end{array}$ \\
Banana & Sugar content & RFLP & $\begin{array}{c}\text { Ming } \text { et al. } \\
(2001)\end{array}$ \\
Grapes & $\begin{array}{c}\text { Seedlessness, } \\
\text { Berry Size, and } \\
\text { Ripening Date }\end{array}$ & $\begin{array}{c}\text { AFLP, SSR, } \\
\text { RAPDs, ISSRs } \\
\text { and SCARs }\end{array}$ & $\begin{array}{c}\text { Mejíal. } \text { al. } \\
(2007)\end{array}$ \\
Strawberry & Day-neutrality & AFLP & $\begin{array}{c}\text { Weebadde } \text { et al. } \\
(2008)\end{array}$ \\
Apricot & Plum Pox Virus & SSR & $\begin{array}{c}\text { Soriano } \text { et al. } \\
(2007)\end{array}$ \\
\hline
\end{tabular}

resistance from peach; $D$, almond shell hardness; $B r$, broomy plant habit; $D l$, double flower; $C s$, flesh color around the stone; $A g$, anther color; $P c p$, polycarpel; $F c$, flower color; $L b$, blooming date; $F$, flesh adherence to stone; $D$, non-acid fruit in peach, $S k$, bitter kernel; $G$, fruit skin pubescence; $N l$, leaf shape; $D w$, dwarf plant; $P s$, male sterility; $S c$, fruit skin color; $G r$, leaf colour; $M a$, nematode resistance from Myrobalan plum; $E$, leaf gland shape; $S f$, resistance to powdey mildew. Genes $D l$ and $B r$ are located on an unknown position of G2.

\section{Varietal identification}

Varietal identification is nothing but DNA fingerprinting. Singly or in groups, molecular markers are capable of producing patterns that are unique for each individual genotype. Their patterns, whether they are generated by PCR or by hybridization with single copy, multicopy, or repeated sequences are referred to as genetic fingerprintings. Few examples of DNA markers used for varietal identification are mentioned in Tab. 7.

\section{Disease diagnostics}

Molecular markers have made it possible to develop diagnostic techniques to identify pathogen with an unprecedented accuracy and speed and to tap genes from as diverse sources as microbes, plants and animals to enable the researchers to develop plants resistant to diseases (Tab. 8).

Tab. 7. DNA Markers for Varietal Identification

\begin{tabular}{ccc}
\hline Crop & Marker Type & References \\
\hline Raspberry & RAPD & Parent et al. (1993) \\
Apple & RAPD & Koller et al. (1993) \\
Grape Cultivar & SSR & Thomas et al. (1995) \\
Grape Roostock & RAPD & Hong Xu et al. (1995) \\
Lemon & RAPD & Deng et al. (1995) \\
Mango & RAPD & Schnell et al. (1995) \\
\hline Blackberry & RFLP & Antonius et al. (1997) \\
\hline
\end{tabular}


Tab. 8. DNA Markers for disease diagnostics

\begin{tabular}{|c|c|c|c|c|}
\hline Character & Fruit crops with population & $\begin{array}{l}\text { Major gene } \\
\text { (symbol) }\end{array}$ & Markers linked & Reference \\
\hline Grey mold (Botrytis cinerea) & Strawberry & & RAPDs & Rigotti et al., 2002 \\
\hline Downy mildew & Vitis vinifera cv. 'Mocato Binaco' x $V$.riparia & & & Marino et al., 2003 \\
\hline $\begin{array}{l}\text { Brown spot disease } \\
\text { (Alternaria alternata) }\end{array}$ & $\begin{array}{l}\text { ‘Clementine’ x 'LB-8-10’ } \\
\text { ('Clementine' x 'Minneola') }\end{array}$ & Aa M1/aaM1 & $\begin{array}{l}\text { P12 (15.3 cM) and AL3 } \\
\quad(36.7 \mathrm{cM}) \text { (RAPDs) }\end{array}$ & Dalkilic et al., 2005 \\
\hline $\begin{array}{l}\text { Eastern filbert blight } \\
\text { (Anisogramma anomala) }\end{array}$ & Hazelnut OSU 245.098 x OSU 408.040 & & $\begin{array}{l}5 \text { AFLP markers } \\
\text { B2-125 at } 4.1 \mathrm{~cm}\end{array}$ & Chen et al., 2005 \\
\hline Citrus tristeza virus & Different citrus hybrids & Ctv-R & RAPDs & $\begin{array}{l}\text { Cristofani } e t \\
\text { al., } 2000\end{array}$ \\
\hline Sharka disease & Apricot (Padre x 54P455) & Y & & Bliss et al., 2002 \\
\hline Citrus nematodes resistance & $\begin{array}{l}\text { LB } 26 \text { (Clementine mandarin x Hamlin sweet } \\
\text { orange) x Swingle citrumelo (C. paradisi }\end{array}$ & & $\begin{array}{l}\text { Markers linked with } \\
\text { Ctv were evaluated }\end{array}$ & Ling et al., 2000 \\
\hline $\begin{array}{l}\text { Plum root nematode } \\
\text { resistance }\end{array}$ & $\begin{array}{l}\text { Bulked segregate analysis of clones } \\
\text { P } 2175, \text { P. } 1079 \text { and P. } 2980\end{array}$ & Mal, Ma2 and Ma3 & $\begin{array}{l}\text { SCAL } 16 \& \text { SCAL } 19 \\
\text { (Practically applied) }\end{array}$ & Lecoules et al., 1999 \\
\hline $\begin{array}{c}\text { Peach root knot } \\
\text { nematodes resistance }\end{array}$ & Peach cv. 'Juseitou' & $\mathrm{Mj}$ & STS-834b & $\begin{array}{l}\text { Yamamoto and } \\
\text { Hayashi, } 2002\end{array}$ \\
\hline
\end{tabular}

Marker Assisted Selection (MAS)

This is one of the important applications of molecular markers. Molecular markers can potentially increase the importance and usefulness of indirect selection in plant breeding. MAS permits the breeder to make earlier decisions about the further selections while examining fewer plants. An added advantage in breeding for disease resistance behaviour is that this could be done in the absence of pathogen once marker information is available. Earlier markers were being developed for monogenic traits but present markers are developed for traits governed by multigenes or polygenes (Tab. 9).

\section{Pedigree analysis and detection of hybrids}

Isozyme analysis has been successfully employed to confirm parentage of plums, apple and mango cultivars

Tab. 9.

\begin{tabular}{ccc}
\hline Fruit & Trait of interest & Reference \\
\hline Apple & Scab resistance & Patocchi et al., 2007 \\
Citrus & Citrus Tristeza Virus & Mestre et al., 2007 \\
Papaya & Fruit skin colour & Inoue et al., 2006 \\
Plum & Root-knot nematodes & Lecouls et al., 2006 \\
\hline
\end{tabular}

and also to establish origin of several pineapple cultivars. Further isozyme been used for differentiating between progeny produced by self pollination and those produced via cross pollination and detection of hybrids. They are used to confirm the production of interspecific prunus hybrids, grape interspecific crosses and progeny screening for hybrid seedlings in citrus breeding programme, besides identification of zygotic and nucellar seedlings in citrus. Vouillamoz and Grando (2006) found that the 'Dureza' and 'Teroldego' were the full siblings and 'Pinot' closely related to 'Syrah'. Similarly, using microsatellite markers, it was found that 'Mission' of California' is similar with 'Pais' (Chile), 'Rosa del Peru' of Peru, 'Negra Corriente' of Peru and 'Criolla Chica' of Argentina. At NRC, grapes, Pune (India), the ambiguity of Dogridge from two different sources (IIHR, Bangalore and American strain) was solved. Dogridge from Bangalore was found to be true to type while Dogridge of America was actually a hybrid and was renamed as B-26 (Upadhyay et al., 2007). The haploid feature between 'Banpeiyu' pummelo (Citrus grandis) $\mathrm{x}$ 'Ruby Red' grapefruit were developed through anther culture. RAPD and isozyme analysis showed that the haploid was from the female 'Banpeiyu' gam. Again its cross with diploid parent 'Kiyomi' as female parent produced fertile unreduced pollen grains. Somatic hybrids integrity is also confirmed with the help of molecular markers in Citrus (Yahata et al., 2005). Based on the phylogenetic analysis with RAPD data, 'Cambu', 'Hongnhieu,' 'Liusun', 'Tieu' and 'Sanh' were clustered in mandarin cluster and $C$. reticulata was assumed to be one of their parents. 'Cam sen', 'Cam Voi', 'Trap', 'Cam Songcon', natural hybrids having unknown genetic origin appeared as genetically closer to the sweet orange (C. sinensis). Similarly, based on RAPD data and morphological characteristics, hybrids of C. maxima and $C$. medica were assumed to origin from 'Bong' and 'Bory'.

Besides the above applications molecular markers are used for negative selection, estimation of genetic contribution by each parent in a segregating population and gene pyramiding

\section{Conclusions}

In terms of scientific progress, the old disciplines of quantitative genetics and plant taxonomy have been revived by the molecular marker approach. The markers have immediate applications in supportive research for 
28

advanced breeding programmes. The major application of markers lies in the strategic research for rapid understanding of basic genetic mechanisms and genome organization at molecular level. The success of DNA marker technology for bringing genetic improvement in fruit crops would depend on close interaction between plant breeders and biotechnologists, availability of skilled man power and substantial financial investment on research.

\section{References}

Shiv, L., A. K. Singh, M. Srivastav, A. K. Dubey and N. K.Singh (2008). Genetic diversity assessment in Indian grape by Simple Sequence Repeats (SSR) markers. India J. of Horti. 65: 4

Adato, A. D., V. Sharon, V. S. Lavi, J. Hillel and S. Gazit (1999). Application of DNA fingerprinting for identification and genetic analysis of mango ( $M$. indica) genotypes. J. Amer. Soc. Hort. Sci. 120:259-64.

Antonius, K. (1999). Molecular markers in Rubus (Rosaceae) research and breeding. J. of Horti. Sci. and Biotech. 74 :149160.

Ashworth, V. E. and M. T. Clegg (2003). Microsatellite Markers in Avocado (Persea mericana Mill.): Genealogical Relationships Among Cultivated Avocado Genotypes Journal of Heredity 94:407-415.

Bartolozzi, F., M. L. Warburton, S. Arulsekar and T. M. Gradziel (1998). Genetic characterization and relatedness among California almond cultivars and breeding lines detected by randomly amplified polymorphic DNA (RAPD) analysis. J. Am. Soc. Hort. Sci. 123:381-87.

Bastianel, M., L. Cristofani-Yaly, A. C. M. Oliveira, J. FreitasAstúa, A. Antonio, G. M. Franco, D. V. Resende, V. Rodrigues and M. A. Machado (2009). Quantitative trait loci analysis of citrus leprosis resistance in an interspecific backcross family of (Citrus reticulata Blanco $\times$ C. sinensis $\mathrm{L}$. Osbeck) $\times$ C. sinensis L. Osb. Euphytica 169:101-111.

Beckman, J. S. and M. Soller (1986). Restriction fragment length polymorphism and genetic improvement of agricultural species. Euphytica 3:111-24.

Bhat, K. V. and R. L. Jarret (1995). Random amplified polymorphic DNA and genetic diversity in Indian. Musa gemplasm GRACO. 42:107-18.

Botstein, J. O., A. Sonko, L. Otten and B. Walter (1993). RFLP molecular taxonomy in Vitis vinifera L. Theor. Appl. Genet. 87:431-38.

Botez, C., R. Sestras, M. Ardelean, D. Pamfil, B. Patrascu and A. Sestras (2009). Phenotypic Selection Assisted by Molecular Markers for Scab Resistance in Apple. Acta Hort. 814:771776.

Bourquin, J. C., A. Sonko, L. Otten and B. Walter (1993). RFLP molecular taxonomy in Vitis vinifera. Theor. and Appl. Genet. 87:431-38.

Brown, N., S. Venkatasamy, G. Khittoo, T. Bahorun and S.
Jawaheer (2009). Evaluation of genetic diversity between 27 banana cultivars (Musa spp.) in Mauritius using RAPD markers. African Journal of Biotech. 8:1834-1840.

Cao, W. H. and Y. R. Zheo (1994). An analysis of isoenzyme and soluble protein in watermelon. Acta Agri. Boreali. Sinica. 9:64-71.

Chemda, D., E. B. Ruth and S. Gazit (1990). Enzyme polymorphism in mango. J. Amer. Soc. Hort. Sci. 115:84447.

Chen, H., S. A. Mehlenbacher and C. D. Smith (2005). AFLP Markers linked to Eastern Filbert blight resistance from OSU 408.040 Hazelnut. J. Amer. Soc. Hort. Sci. 130(3):412-17.

Coart, E., X. Vekemans, M. J. M. Smulders, I. Wagner, J. Van Huylenbroeck, E. Van Bockstaele and I. Roldán-Ruiz (2003). Genetic variation in the endangered wild apple (Malus sylvestris L. Mill.) in Belgium as revealed by amplified fragment length polymorphism and microsatellite markers. Mol. Ecology 12:845-857.

Deng, Z. N., A. Gentle, E. Nicolosi, F. Domina, A. Vardi and E. Tribulata (1995). Identification of in vitro and in vivo lemon mutants by RAPD markers. J. Hort. Sci. 70:117-25.

Dewald, M. G., G. A. Moore and W. B. Sherman (1992). Isozyme in Ananas (Pineapple): Genetics and usefulness in taxonomy. J. Amer. Soc. Hort. Sci. 117:491-96.

Durham, R. E., P. C. Liou, F. G. Gmitter and G. A. Moore (1992). Linkage of restriction fragment length polymorphism and isozymes in Citrus. Theor. and Appl. Genet. 84:39-48.

Durham, R. E., G. A. Moore and W. B. Sherman (1987). Isozyme banding patterns and their usefulness as genetic markers in peach. J. of Amer. Soc. Hort. Sci .112:1013-18.

Etienne, C., C. Rothan, A. Moing, C. Plomion, C. Bodenes, D. L. Svanella, P. Cossen, V. Pronier, R. Monet and E. Dirlewanger (2002). Candidate genes and QTLs for sugar and organic content in peach, Prunus persica (L) Batsch. Theor. and Appl. Genet. 105:145-59.

Gawel, N., R. L. Jarret and A. T. Whittemore (1992). Restriction fragment length polymorphism (RFLP) based phylogenetic analysis of Musa. Theor. and Appl. Genet. 84:286-90.

He, X., G. Yong-zeb, L. Yang-ruia and O. Shi-jinb (2007). Assessment of the Genetic Relationship and Diversity of Mango and Its Relatives by cpISSRMarker. Agricultural Sciences in China 6:137-142.

Hong, X., J. W. Diane, S. Aulsekar and T. B. Alan (1995). Sequence specific PCR markers derived from rapid markers for fingerprinting grape (Vitis) root stocks. Jr. Amer. Soc. Hort. Sci. 120:714-20.

Inouea, E., M. Kasumib, F. Sakumac, H. Anzaid, K. Amanoa and H. Haraa (2006). Identification of RAPD marker linked to fruit skin color in Japanese pear (Pyrus pyrifolia Nakai) Scientia Horti. 107:254-258.

Joshi, S. P., P. K. Ranjekar and V. S. Gupta (1999). Molecular markers in plant genome analysis. Curr. Sci. 77:230-40.

Koller, B., A. Lehman, J. M. McDermott and C. Gessier (1993). 
Identification of apple cultivars using RAPD markers. Theor. and Appl. Genet. 85:901-04.

Lu, Z. X., G. L. Reighard, W. V. Baird, A. G. Abbott and S. Rajapakse (1996). Identification of peach rootstock cultivars by RAPD markers. Hort. Sci. 31:127-129.

Marcela, D. M., S. G. Ingrid, R. G. E. Manuel and H. Jaramillo (2009). Analysis of diversity among six populations of Colombian mango (Mangifera indica L. cv. Hilacha) using RAPDs markers. Electronic Journal of Biotech. 12:1-6.

Market, C. L and F. Moller (1959). Multiple forms of enzymes tissue ontogenic and specific patterns. Pro. of Nat. Acad. of Sci. 45:753-763.

Martin, G. B., J. G.K. Williams and S.D. Tanksley (1991). Proc. Natl. Acad. Sci. USA 88:2336-40.

Mejía, N., M. Gebauer, L. Muñoz, N. Hewstone, C. Muñoz and P. Hinrichsen (2007). Identification of QTLs for Seedlessness, Berry Size, and Ripening Date in a Seedless x Seedless Table Grape Progeny. Am. J. Enol. Vitic. 58:499-507.

Mestre, P. F., M. J. Asíns, J. A. Pina, E. A. Carbonell and L. Navarro (2007). Molecular markers flanking citrus tristeza virus resistance gene from Poncirus trifoliata (L.) Raf. Theor. and Appl. Genet. 94:458-464.

Ming, R., S. C. Liu, P. H. Moore, J. E. Irvine and A. H. Paterson (2001). QTL Analysis in a Complex Autopolyploid:Genetic Control of Sugar Content in Sugarcane. Genome Res. 11: 2075-2085.

Mullis, K. B., F. Faloona, S. Scharf, R. Saiki, G. Horn and H. Erlich (1986). Specific enzymatic amplification of DNA in vitro: the polymerase chain reaction. Cold Spring Harbor Symp. Quanti. Biol. 51:263-73.

Meyer, W., T. G. Michell, E.Z. Freedman and R. Vilgalys (1993). Hybridization probes for conventionalDNA fingerprinting used as single primers in polymerase chain reaction to distinguish strain of Cryptococcus neoformans. J Clin Biol 31: 2274-2280.

Nagaoka, T. and Y. Ogihara (1997). Applicability of intersimple sequence repeat polymorphisms in wheat for use as DNA markers in comparison to RFLP and RAPD markers. Theor. and Appl. Genet. 94:597-602

Parent, J. G., M. G. Fortin and D. Page (1993). Identification of Raspberry cultivars by Random Amplified Polymorphic DNA (RAPD analysis). Canad. J. Pl. Sci. 73:1115-22.

Patocchi, A., E. A. Frei, E. J. E. Frey and E. M. Kellerhals (2009). Towards improvement of marker assisted selection of apple scab resistant cultivars: Venturia inaequalis virulence surveys and standardization of molecular marker alleles associated with resistance genes. Mol Breeding 24:337-347.

Peterson, A. H., S. D. Tanksley and M. E. Sorrels (1991). DNA markers in plant improvement. Adv. Agron. 46:39-90.

Rajapakse, S., L. E. Belthoff, G. He, A. E. Estager, R. Scorza, I. Verde, R. E. Ballard, W. V. Baird, A. Callahan, R. Monet and A. G. Abbott (1995). Genetic linkage mapping in peach using morphological, RFLP and RAPD markers. Theor.
Appl. Genet. 90:503-10.

Riaz, A., L. Ferguson and M. S. Stephen (2003). Identification of Pistachio (Pistacia vera $\mathrm{L}$ ) Nuts with microsatellite markers. J. Amer. So. Hort. Sci. 128:898-903.

Schnell, R. J., G. N. Ronning and G. L. Knight (1995). Identification of cultivars and validation of genetic relationships in Mangifera indica L. using RAPD markers. Theor. and Appl. Genet. 90:269-74.

Sestras, R., D. Pamfil, M. Ardelean, C. Botez, A. Sestras, C. Dan and L. Mihalte (2009). Use of Phenotypic and MAS Selection Based on Bulk Segregant Analysis for Study of Genetic Variability Induced by Artificial Hybridization on Apple. Notulae Botanicae Horti Agrobotanici Cluj-Napoca 37(1):273-277.

Shiran, B., N. Amirbakhtiar, S. Kiani, S. Mohammadi, B. E . Sayeed and H. Moradi (2007). Molecular characterisation and genetic relationship among almond cultivars assessed by RAPD and SSR markers. Scientia Hort. 111:280-292.

Sisko, M., B. Javornik, A. Siftar and A. Ivancic (2009). Genetic relationships among Slovenian pears assessed by molecular markers. J. Amer. Soc. Hort. Sci. 134:97-108.

Soriano, J. M., E. M. Vera-Ruiz, S. Vilanova, J. MartínezCalvo, G. Llácer, M. L. Badenes and C. Romero (2007). Identification and mapping of a locus conferring plum pox virus resistance in two apricot-improved linkage maps. Tree Genetics and Genomes 4:391-402

Southern, E. M. (1975). Detection of specific sequences among DNA fragments separated by gel electrophoresis. J. Mol. Bio. 98:503-17.

Strauss, S. H., J. Bonsquet, V. D. Hipkins and Y. P. Hong (1992). Biochemical and molecular genetic markers in biosystematic studies of forest trees. New Forests 6:125-158.

Sylwia, K. P., L. Mariusz and K. Malgorzata (2009). Molecular screening of apple (Malus domestica) cultivars and breeding clones for their resistance to fire blight. Journal of Fruit and Ornamental Plant Res. 17:31-43.

Thimmappaiah, W. G., D. Santhosh Shobha and G. S. Melwyn (2009). Assessment of genetic diversity in cashew germplasm using RAPD and ISSR markers. Scientia Hort. 120:411417

Vos, P., R. Hogers, M. Bleekar, M. Reijans, T. Vandele, M. Hornes, A. Fritjers, J. Pot, J. Pelemman, M. Kuiper and M. Zabeau (1995). AFLP: A new technique for DNA finger printing. Nucleic Acid Research. 23:4407-14.

Walker, M. A. and L. Liu (1995). The use of isozymes to identify 60 grapevine rootstocks (Vitis spp.). Amer. J. Enol. Viticult. 46:299-305.

Wang, D., R. Karle and A. F. Iezzoni (2000). QTL analysis of flower and fruit traits in sour cherry. Theor. and Appl. Genet. 100: 535-44.

Warburton, M. L. and F. A. Bliss (1996). Genetic diversity in peach (Prunus persica L. Batch) revealed by randomly amplified polymorphic DNA (RAPD) markers and 
30 compared to unbreeding coefficients. J. Am. Soc. Hort. Sci. 121: 1012-19.

Weebadde, C. K., D. Wang, C. E. Finn, K. S. Lewers, J. J. Luby, J. Bushakra, T. M. Sjulin and J. F. Hancock (2008). Using a linkage mapping approach to identify QTL for dayneutrality in the octoploid strawberry. Plant Breeding 127 94-101.

William, J. G. K., A. R. Kubelik, K. I. Livak, J. A. Rufalski and S. V. Tingay (1990). DNA polymorphism amplified by arbitrary primers are useful as genetic markers. Nucleic Acid
Res. 18: 6531-35.

Yamamoto, T., T. Kimura, J. Soejima, T. Sanada, Y. Ban and T. Hayashi (2004). Identification of Quince varieties using SSR markers developed from pear and apple. Breeding Sci.54: 239-44.

Zietkiewicz, E, A. Rafalski and D. Labuda (1994). Genome fingerprinting by simple sequencerepeat (SSR)-anchored polymerase chain reaction amplification. Genomics. 20:176183. 